\title{
Getting to Know about Readability Level
}

\author{
Dhion Meitreya Vidhiasi \\ Akademi Maritim Nusantara, Cilacap \\ mvdhion@gmail.com
}

Diterima 01 Februari 2021, direvisi 08 Februari 2021, diterbitkan 08 Maret 2021

\begin{abstract}
English is a language that is still difficult to "conquer", especially with its status as a foreign language. Not only is it difficult in terms of pronunciation, but also most Indonesians still have difficulty understanding the English translation text that has been translated into Indonesian. This study will explain the level of readability of a reading text. The level of readability greatly affects how a text can be understood by readers who come from the target language. There are 3 (three) readability levels: high, medium, and low readability. In addition, there are several things that affect the readability of a translated text, such as the use of new words, idioms, and taxa sentences. Translating a word or a reading text not only requires knowledge of translation techniques but also the translator's competence and understanding of the context of the text to be translated.
\end{abstract}

Keywords : Translation, Readability Level, Source Language, Target Language

\begin{abstract}
Abstrak
Bahasa Inggris merupakan bahasa yang masih menjadi hal yang sulit "ditaklukan", terlebih dengan statusnya sebagai bahasa asing. Bukan hanya sulit dalam hal pengucapan, namun juga kebanyakan orang Indonesia masih sulit memahami teks terjemahan Bahasa Inggris yang sudah diterjemahkan ke Bahasa Indonesia. Penelitian ini akan menjelaskan tentang tingkatan keterbacaan dari suatu teks bacaan. Tingkatan keterbacaan sangat mempengaruhi bagaimana usatu teks dapat dipahami oleh pembaca yang berasal dari bahasa tujuan. Ada 3 (tiga) tingkat keterbacaan yatu keterbacaan tingkat tinggi, tingkat sedang, dan tingkat rendah. Selain itu, ada beberapa hal yang mempengaruhi tingkat keterbacaan suatu teks terjemahan seperti penggunaan kata baru, idiom, hingga kalimat taksa. Menerjemahkan suatu kata maupun teks bacaan tidak hanya membutuhkan pengetahuan tentang teknik penerjemahan melainkan juga kompetensi dan pemahaman si penerjemah terhadap konteks suatu teks yang akan diterjemahkan.
\end{abstract}

Kata kunci $\quad$ : Penerjemahan, Tingkat Keterbacaan, Bahasa Sumber, Bahasa Sasaran 


\section{Introduction}

English is a good language to be known since it is a universal language. People use English to communicate each other need to have a good understanding not only an understanding of English itself but also the meaning of the utterance. For beginner or mostly students, they tend to translate first the English into their own mother tongue, then they start communicate with it.

People sometimes tend to feel confuse in understanding not only English book but also the translated one. The translated version of a book is supposed to be an aid for those who cannot understand English well. In fact, some translated version of a book cannot accommodate this problem even make the reader getting more confuse in absorbing the information of a book.

There are three basic principles of a good translation; those are accuracy, acceptability, and readability. Readability level can be considered as one of an important aspect in translation. Translator sometimes feels that if a text from source language (SL) has already been translated into target language (TL) then the work is done. In fact, translators should consider the readability level of their work; is it easy to be understood or not. Translation should possess the style of translation. It means that the translated version of a text should have a style of target language [1]. Readability is explained as the ease of understanding or comprehension due to the style of writing [2].

There are some factors influenced the level of readability; those are the use of new words, ambiguous words, idioms, and complex sentences [3]. It can be concluded that in order to make a text which has a high level of readability, translator should find the equivalence of those factors. This research will explain more about readability level in order to understand Maritime English.

\section{Reading}

Reading is a purpose creating method [4]. It is necessary to know the correct word spelling, but without a correct comprehension of significance, the reader would be unable to comprehend to what they read.

There is a disparity between the method of reading and the result. The description of the method of reading is assumed to be a right reading. Proper reading describes reading as a reader-text connection [5]. It's not as straightforward as this contact seems. When the reading process takes place, certain things happen. When you read a letter, the reader can say a lot. The method will differ from one reader to the next. The reading method is normally calm, confidential and internal.

Readers play a significant part in interpreting the wording. They are the ones that make sense. They don't just read the words to say the shake. They do a lot of things: connect the meaning of the words or expressions, construct visual pictures or interact with characters emotionally or even foresee what's coming.

\section{Readability}

Document readability is the comfortable reading and comprehension written content [6]. In accordance with Richard, argued that readability is the degree to which a text can be read and understood. It is evident from these two meanings that readability applies to the reader as the subject deciding the readability of a text [7].

An inventory was made of at least a variety of readability considerations. This include: 1) the average sentence length, 2) new word numbers, 3 ) the grammatical structure of the language employed [7]. It is also suggested that, aside from these influences, factors of language usage are very important, such as the use of nonwritten new words, the use of uncommonly interpreted foreign words, and the use of taxa (ambiguous) [7].

Apart from the word level, it is definitely difficult for readers to use foreign language sentences, taxa phrases, fragmented sentences, difficult sentence phrases, sequential phrases, or lengthy duration and decreases reading readability. The readability is often influenced, apart from the text itself, by readers' educational and cultural history.

In order to know the readability of the translation output, paragraph units do not have to include sentences so the reader cannot grasp the whole meaning of the translation if only at the sentence level. The explanation for picking paragraphs is that paragraphs consist of multiple phrases creating a shared understanding the extent of the readability [8]. If the paragraph is easy to comprehend, the text is readable well. In addition to having a closed response, Nababan also proposed giving room to readers' remarks. 
A scale and standards have been established in line with the above criteria to make it easier to determine errors. In this report, the exactness scale will be modified based on the parameters suggested by Nagao, Tsujii and Nakamura since this model is more realistic for quality control based upon translation strategies rather than the scale [8]. Scales are obviously key instruments in translation assessment (when it is the product that is to be assessed) [9]. This scale also shows the type of error found in the effects of translation. In addition to accuracy, the readability aspect of target readers will also be observed to determine the consistency of the translation in this review [8].

The context of readability is not only in the context of source language but also in target language. Readability is the easiness level of a text to be read and understood. It is about how the reader can understand the message of a text easily [7]. The problem is that the indicator to assess a readability level of a text is still questionable. Besides the translator should know source language and target language, the translator should also know the concept of readability itself. Some factors influenced the level of readability are [3]:

\section{New Words}

A text with foreign language sometimes has some foreign terms or maybe local language that is still cannot be understood by some people. We can find the terms if it relates the culture of one area. For example the word siraman in Javanese marriage tradition cannot be translated as showering or bathing since the true meaning of the word will be very different. Literally, Siraman here means to take a bath. It is not an ordinary "taking a bath" if we take a look at the process and the function. The meaning of siraman is to clean the brides' body and soul. It has a deep cultural meaning in Javanese cultural of marriage.

This factor makes a text has a low level of readability if the translator cannot understand the context of the text. Therefore in order to make the text readable, translator should understand target language very well; not only the system of the language but also the culture. If we as translator find such new words, we can use the definition technique or using foot note in order to translate or explain those new words.

\section{Ambiguous Words}

Ambiguous word means that one word has more than one meaning. If the reader reads only the translated version of a text, it probably seems okay if the translator gives a wrong translation of something. The problem maybe is just the naturalness of reading. When the reader compare the same text with different language, maybe this time the reader will find that there is a wrong translated word found in the text. If such case happens, it can be said that the text is unreadable.

Translating an ambiguous word needs a good understanding of the context of the text. For example, the translation of the word bridge into Indonesian language. If the context is a bridge found on the ship, then the perfect translation is anjungan. Bridge can be translated as jembatan if the context is for a thing used to cross people from one side to another side of a place. The translator should understand the context of the text in order to avoid a kind of wrong translation.

\section{Idiom}

Idioms are type of formulaic language. It is a fixed combination of words whose meaning is often difficult to guess from the meaning of each individual word [10]. It means that idioms must be understood as units rather than as individual words.

They also explain that idioms are constructed in different ways. It means that idioms are words, phrases, or expressions that are either grammatically unusual, as in long time no see, or their meaning cannot be taken literally, as in it's raining cats and dogs. Raining cats and dogs does not mean that cats and dogs are falling from the sky, but it is a metaphorical expression for raining very heavily. Another example of idiom is the phrase break a leg. It cannot be translated into patahkan kaki in Indonesian because the meaning will be incorrect. An idiom break a leg is the same as good luck or semoga sukses in Indonesian.

It can be seen that sometimes the construction of the idiom is grammatically unusual. Understanding idioms will be very hard if the translator do not know the context of the idiom. By learning idioms, we will learn a lot about the culture of a country. That is why translators should have such knowledge like idiom to make their translated text readable. 


\section{Readability Level}

A high level of readability defines a positive outcome of a translation work. A highly understandable translation is a work that the reader readily understands. This can be rendered by omitting several foreign words that render interpreting the effects of the translation challenging for the reader. However, in the form of expression, paraphrase or sentence, the translator will attempt to provide suitable equivalent. A translation outcome that typically fits the laws of the source language is hard to grasp in the target language for the reader.

The rigid language of a translation outcome is generally because the translator uses a word for word or a literal translation of a source language text without modifying the original language type into a target language text. Each language has its own distinctive character, and it has not the same matches as other languages, with a separate linguistic system. The language level cannot then only be translated to the target language in the source language in the translation.

A valuation of a translated text should be made in order to know whether the text is readable or not. Assessing a readability level of a text cannot be done just by looking at sentence by sentence, but it should be in a whole package of a paragraph or a text. There are 3 (three) readability level based on the model explained by Nababan, those are: high, medium, and low [11].

\section{High Readability Level}

A translation is said to have a high readability level when the readers have no difficulties in understanding the target text. The readers read the text easily and fluently. The impact of a high readability level is the message contain in the text can be easily transferred to the readers through the target language.

The implementation of high readability level can be seen from the example I wear a blue shirt. It can be translated as Saya mengenakan baju biru in Indonesian. The information of the utterance can be transferred very well into the readers through the target language. The readers will not find any difficulties in understanding that information.

\section{Medium Readability Level}

The readers sometimes will find one or two difficulties in understanding a translated text. This kind of text can be considered as a text which has a medium readability level. It means that there are some but not many of difficult or maybe foreign words found in the text that a little bit hard to be understood by the readers. The existence of complex sentence and wrong choice of punctuation can also be the factors that make the text have medium readability level.

The word bridge is a kind of ambiguous word because we need to see the context of the text first. Bridge in general term will be translated as jembatan in Indonesian or a thing used to cross people or thing from one side to another side of a place. It will have different meaning if the context is a bridge on a ship. That word can be translated as anjungan in Indonesian or a command room of a ship where ship's wheel and other navigating equipment are located. It can be concluded that the understanding of a context of the text is a must in order to get the information of the text.

\section{Low Readability Level}

This kind of level shows that the readers are hard to understand the text. The readers are hard to catch the meaning of the text. Sometimes the reader will find so many foreign terms, complex sentences, and wrong choice of punctuation. A text that tells about philosophy or ideological thing can be considered as the text which has a low readability level. Text with cultural thing can also be considered as one too.

Javanese wedding has a ritual called siraman. The purpose of that ritual is to clean the body and soul of the brides. It has a sacral meaning. When the translators translate siraman as bathing or showering in English without giving any definition, it will be difficult to understand the meaning of the word. Bathing or showering is a kind of daily activity while siraman is a special ritual of Javanese wedding ceremony. Here translators must have an understanding of the culture of a country in order to make a good translation.

\section{Conclusion}

Understanding a word, especially reading text in foreign languages, is not easy. This is not surprising considering English is a foreign language in Indonesia. Often the translators 
translating English into Indonesian as the target language experience problems. Understanding English in accordance with its field is very important in translating a particular document.

Translating and understanding Maritime English cannot be equated with the use of English in general. Terms such as "bridge" and "bows" cannot be translated as "jembatan" and "busur panah" when linked to the context of Maritime English. It can be concluded that the level of readability of a word or translated text is not only determined by the translator's knowledge of translation techniques but also the translator's understanding of the context of the reading text to be translated.

\section{Note}

The author would like to thank the Akademi Maritim Nusantara Cilacap for providing support to the author so that this research can be published.

\section{Bibliography}

[1] P. Newmark, "A textbook of translation" Vol. 66, New York, Prentice hall, (1988).

[2] W. H. DuBay, "The Principles of Readability", California, California State University, 2004.

[3] M. R. Nababan, "Aspek Teori Penerjemahan dan Pengalihbahasaan", Surakarta, UNS Press, 1997.

[4] J. S. Caldwell, "Reading Assessment", New York, The Guilford Press, 2008.

[5] J. C. Alderson, "Assesing Reading", New York, Cambridge University Press, 2001.

[6] J. C. Richards \& R. Schmidt, "Longman dictionary of applied linguistics and language teaching", Harlow, UK, Longman, 2002.

[7] M. R. Nababan, "Teori Menerjemah Bahasa Inggris", Yogyakarta, Pustaka Pelajar, 2003.

[8] M. R. Nababan, "Strategi penilaian kualitas terjemahan dalam Jurnal Linguistik Bahasa (JLB)”, 2004.

[9] N. Martínez Melis, \& A. Hurtado Albir, "Assessment in translation studies: Research needs". Meta: journal des traducteurs/Meta: Translators' Journal, 46(2), 272-287, (2001).

[10] F. O'Dell, \& M. McCarthy, "English idioms in use advanced with answers", Cambridge University Press, 2010.
[11] W. Kurnianingtyas, "Kualitas Hasil Penerjemahan Individu Dan Penerjemahan Kelompok (Studi Kasus Proses dan Hasil Penerjemahan Mahasiswa Pascasarjana Program Studi Linguistik Minat Utama Penerjemahan Universitas Sebelas Maret Surakarta)", Surakarta, Universitas Sebelas Maret, 2008. 